\title{
Medicinska sestra u timu za izvođenje epikardneablacije
}

\author{
Mila Vukadinović, viša medicinska sestra \\ Institut za kardiovaskularne bolesti Dedinje
}

Sažetak: Svaki poremećaj normalnog srčanog ritma, pri kome dolazi do povećenja ili smanjenja frekvencije (brzine rada srca) ili preskaknja u radu srca zovu se aritmije. Različite su vrste aritmija i mogu se podeliti na: atrijalne fibrilacije (treperenje pretkomora), ekstrasistole, $W$-P-W sindrom, ventrikularna tahikardija, bradikardijai ventrikularna fibrilacija (životno ugrožavajuća). Uzroci aritmija mogu biti akutni infarkt miokarda, prolaps mitralne valvule, kardiomiopatija, miokarditis, urođene srčane mane, bolesti srčanih zalistaka, kofein, droge, stres....

Epikardna ablacija je invazivno nehiruško lečenje aritmije koje se koristi u lečenju malignih ventrikularnih aritmija. Izvodi se u lokalnoj anesteziji. Lekar uvodi kateter uperikardnu kesu i sa spoljašnje strane srca traži mesto koje je uzrok aritmije (obično se radi o snopiću ili čvoriću na određenom mestu u srcu), orjentišući se pomoću rentgenske slike i EKG-e zapisa koji dobija sa vrha katetera. Kad pronađe pravo mesto, pomoću radiofrekventne energije zagreva vrhovog katetera i na taj način namerno stvara malo i ograničeno oštećenje tog dela mišića (veličine 1-2mm), čime se uništava aktivnost čvorića koji je uzrok aritmije.

Kod dobro odabranih pacijenata, ovo je danas metoda izbora u lečenju, jer može značiti izlečenje, tj potpuni prestanak aritmije, zauvek, bez potrebe za daljim uzimanjem lekova.

Ključne reči: aritmija, epikardna ablacija, kateter, mapiranje, monitoring

Abstract: Any disturbance of the normal heart rhythm, during which there is an incease or decrease in frequency (heart rate) or similar abnormalities is called cardiac arrhythmia. There are different types of arrhythmias which can be divided into: atrial fibrillation (atrial flicker), premature ventricular contraction, WPW syndrome, ventricular tachycardia, bradycardia end ventricular fibrillation (life-threatening). The causes of arrhythmias may be acute myocardial infarction, mitral valve prolapse, cardiomyopathy, myocarditis, congenital heart defects, valvular heart disease, caffeine, drugs, stress ....

Epicardial ablation is an invasive non-surgical treatment of arrhythmias and is used in the treatment of malignant ventricular arrhythmias. It is performed under local anesthesia in the following way: a catheter is introduced by the physician into the pericardial sack and the outside of the heart, to search for the spot that is causing arrhythmias (usually in bundles or lumps at particular place in the heart), using X-ray images and EKG records obtained from the catheter tip for navigation. Once the right position has been found, the tip of the catheter is heated by radio frequency energy, allowing for small, deliberate damage to be done to parts of the muscle (1-2mm in size), which breaks the conductive wisp or destroys the activity of the nodes that cause arrhythmias.

In well-selected patients, this is currently the method of choice in treatment because it may cure, or cause a complete cessation of arrhythmias in perpetuity, without the need for further drug taking.

Keywords: arrhythmias, epicardial ablation catheter, mapping, monitoring

\section{UVOD}

Srčane aritmije su veoma značajna srčana oboljenja, što potvrđuje procena da u Srbiji pet do šest hiljada osoba naprasno umire od malignih poremećaja ritma. I pored velikog napretka u dijagnostikovanju i lečenju još uvek na naslovnim stranama novina osvane naslov da je neki sportista naprasno premunuo na terenu.

Dijagnostikovanjem i lečenjem aritmija se bavi grana kardiologije - elektrofiziologija. Koristeći se raznim invazivnim i neinvazivnim testovima precizno utvrđuje vrstu i poreklo aritmije. Lečenje se sastoji od medikamentozne terapije a u novije vreme, dafinitivni metod lečenja je radiofrekventna ablacija aritmogenog žarišta. To se postiže na dva načina: endokardno - kada je žarište unutar srčanih šupljina i epikardno - kada se žarište nalazi sa spoljašnje strane srca.

Odgovornost za staranje o bolesnicima sa ovim poremećajima prenosi se skoro na svaku oblast sestrinske prakse. Nega u oblasti elektrofiziologije predstavlja jednu od obalsti nega koja se najbrže razvija i menja sa konstantnim uvećavanjem novih dijagnostičkih testova, novih lekova i metoda lečenja sa sve sofisticiranijom opremom. Zbog toga su sestre suočene sa stalnim izazovom da prate najnovija dostignuća.

Zbog potreba bolesnika i sagledavanja njegovog kompletnog stanja formiraju se timovi. Oni su sačinjeni od profesionalaca raznih profila: doktori, mediciske sestre, rentgen tehničari, inžinjer informatike i dr. Svi članovi tima imaju u svojoj nadležnosti određene zadatke i ciljeve.Timskim radom se podiže kvalite rada, bolesnici i njihove porodice su zadovoljniji i smanjuje se stres članova tima.

Medicinska sestra je, pored doktora, najbitniji član tima. Da bi što kvalitetnije mogla da učestvuje u timskom radu neophodno je da ima znanja o nastanku premećaja ritma, normalnom izgledu EKG kao i da prepozna pojavu i vrstu aritmija. Treba da zna kako se izvodi epikardna ablacija i koje komplikacije mogu da se pojave kako bi na vreme uočila prve simptome i na taj način doprinela boljem i kvalitetnijem lečenju.Nepohodno je da poznaje aparaturu sa kojom rukuje i da u svakom trenutku zna da je upotrebi. 


\section{DIJAGNOSTIČKE PROCEDURE U POSTAVLjANjU INDIKACIJE ZA EPIKARDNU ABLACIJU}

Aritmiju mogu da izazovu različite bolesti kao i stres, konzumacija alkohola i kofeina, pušenje, alkohol, dijetalne pilule, kašalj, anemija, dijafragmalna kila i dr. Nema uvek odnosa između tegoba i aritmije, neke osobe sa vrlo opsnbim aritmijama nemaju nikakve simptome, dok bezopasne aritmije kod nekih bolesnika izazivaju neprijatne simptome. Najčešći simptomi koji dovode bolesnika kod doktora su: ubrzan rad srca (tahikardija), treperenje u grudnom košu, stenokardija (pritisak i bol u grudnom košu), zadihanost, nesvestice, vrtoglavice, slabost, sinkopa (gubitak svesti).

Osnova u postaljanju dijagnoze je detaljno uzimanje podataka o simptomima i fizikalni pregled koji podrazumeva EKG i laboratirijske analize.

Često je neophodno pregled dopuniti ehokardiografskim ispitivanjem, holtermonitoringom, ergometrijskim testom odnosno testomopterećenja. Nekibolesnicizahtevajui invazivnoelektrofiziološko dijagnostičko ispitivanje.

\section{Elektrokardiogram - EKG}

Predstavlja beleženje električnih potencijala kao odraza električne aktivnost srca pomoću elektroda koje se postavljaju na površinu tela. U svakodnevnoj praksi se snima 12 odvoda: 3 standardna ili bipolarna koji se obeležavaju rimskim brojevima I,II,III; 3 unipolarna odvoda koji se obeležavaju aVR, aVL, aVF; i 6 prekordijalnih odvoda koji se obeležavaju V1-V6. Zapis se vrši na milimetarskom papiru a uobičajena brzina kretanja papira je $25 \mathrm{~mm}$ u sekundi. Prilikom zapisivanja EKG-a može doći do tehničkih nedostataka zbog pojave parazitarnih struja iz gradske mreže, zamene elektroda, tremora ili nemira bolesnika. Dužnost sestre je da precizno uradi EKG, napiše ime i prezime bolesnika i pokaže lekaru radi daljeg tumačenja.

\section{Holtermonitoring}

Predstavlja dijagnostičku metodu koja ima široku primenu u praksi. Služi za otkrivanje srčanih aritmija i poremećaja u sprovođenju impulsa. Za vreme snimanja kontinuiranog EKG-a bolesnik ima fiksirane elektrode na grudnom košu koje su priključkom spojene sa rekorderom koji u sebi sadrži magnetnu traku ili memorijsku karticu u koju se snimaju podatci i pogonsku bateriju. Pre početka snimanja potrebno je pravilno postaviti elektrode i dobro ih zalepiti za kožu i baždariti uređaj. Posle 24 sata snimanja vrši se očitavanje zapisa pomoću kompjuterskih programa. U toku snimanja bolesnik vodi dnevnik o aktivnostima i eventualnim subjektivnim poteškoćama kao što su dispneja, osećaj lupanja srca, anginozni bol, vrtoglavice, omaglice, sinkope. U toku očitavanja zapisa upoređuju se EKG promene sa subjektivnim tegobama.

\section{Ergomerija}

Predstavlja neinvazivnu dijagnostičku metodu, kojom se bolesnik izlaže standardizovanom i merljivom opterećenju. Obavlja se na bicikl-ergometru ili pokretnoj traci a opterećenje je konstantno i progresivno. Ovim testom se određuje postignuto opterećenje, frekvencija srca, visina krvnog pritiska i EKG promene u toku i posle opterećenja. EKG se kontinuirano prati na monitoru u toku i posle opterećenja, a snima se na početku testa, svake prve i treće minute svakog stepena opterećenja i posle opterećenja. Test se prekida kada se postigne zadato opterećenje ili u slučaju pojave anginoznog bola, ST depresije, hipertenzije, pojave polimorfnih ekstrasistola, ventrikularne tahikardije, pada frekvencije i hipotenzije.

Ehokardiografija
Predstavlja dijagnostičku metodu, koja koristi ultrazvučne signale koji se reflektuju od srčanih struktura i stvaraju sliku na monitoru o anatomskim odnosima, morfološkim i funkcionalnim promenama. Veoma je značajna u pripremi bolesnika za predstojeću epikardnu ablaciju, proveru stanja srčanog mišića kao i u kontroli perikardnog izliva po završenoj proceduri. Ehokardiografija se radi u kabinetu za ultrazvučnu dijagnostiku u kome rade posebno edukovane VMS.

\section{Skener grudnog koša}

Predstavlja radilošku metodu ispitivanja koja pored rentgen zračenja primenjuje i tomografiju, metodu koja se zasniva na matematičkoj proceduri obrade snimaka ili tomografskoj rekonstrukciji snimaka uz primenu savremenih računara i programskih paketa u njima. Metoda digitalne geometrijske obrade se koristi za generisanje trodimenzionalnih slika unutrašnjosti snimljenog organa koju čini velika serija dvodimenzionih rentgenskih snimaka snimljenih u toku jedne rotacije uređaja oko svoje ose. Skenersko ispitivanje grudnog koša može da otkrije razne anomalije srca i krvnih sudova, precizan polozaj koronarnih arterija, specifičnu anatimiju perikarda i da na taj nečin pripremi lekara za bezbedno izvođenje epikardne ablacije.

\section{Eektrofiziološko ispitivanje}

Predstavlja invazivnu metodu kod koje se u lokalnoj anesteziji, kroz venu u preponi, ulazi sa kateterima u srce i na određenim tipičnim mestima snima EKG u samom srcu. To je, ponekad, od velike važnosti kako bi se postavila tačna dijagnoza (postoje aritmije kod kojih je to moguće učiniti jedini na taj način) i precizno opisao električni sastav srca i njegove anomalije. Tokom postupka moguće je izazvati i prekinuti aritmiju koju bolesnik prepoznaje kao svoj problem. Radi se o ekstremno sigurnom zahvatu sa izuzetno retkim komplikacijama. Ova vrsta ispitivanja zahteva hospitalizaciju bolesnika i ne spada u rutinske metode ispitivanja.

\section{EPIKARDNA ABLACIJA}

Naosnovu svih predhodnih testova, stanja bolesnika i njegovih želja doktori donose najbolju odluku za dalje lečenje. Prvo, se predlaže standardno medikamentozno lečenje. Najčešće korišćeni lekovi za lečenje poremećaja ritma su: antiartimici, beta blokatori, blokatori kalcijumskih kanala, sedativi i dr. Oni kod pojedinih bolesnika mogu imati mnoga neželjena dejstva.

Kod pojedinih poremećaja ritma i pored redovne upotrebe lekova dolazi do pojave napada tahikardije koje ih remete u sakodnevnom radu i životu i zahtevaju čestu hospitalizaciju i defibrilaciju su kandidati za invazivno lečenje aritmije.

Bolesnici sa ishemijskom bolešću srca imaju velike endokardne ožiljke i kod njih je češća subendokardna lokacija žarišta ventrikularne tahikardije. Kod bolesnika sa neishemjiskom kardiomipoatijom zbog dilatiranog srčanog mišića registrovana su polja sa niskom voltažom koja su povezana sa postojanjem ožiljaka, koji su u većini slučajeva artimogena žariša.

Najbitniji deo epikardne ablacije predstavlja mapiranje pomoću tri-de navigacionog sistema. On doktorima omogućava da vide realnu sliku svih komora i predkomora kao i spoljašnju stranu srca sa svim njenim specifičnostima. Mapingom se pronalazi tačno mesto u srcu gde nastaju aritmije i tada se kroz kateter propušta radiofrekventa energija. Nakon toga bolesnik je izlečen. Iako ovo deluje kao vrlo laka i jednostavna intervencija, ablacije traju i po nekoliko sati. Kretanje katetera po srcu se sve vreme prati uz pomoć rentgena. Kateterom se dolazi do mesta na koje nam predhodna ispitivanja 
ukazuju kao izvor aritmije i tu se mere elekteični potencijali. Ovo pronalaženje mesta traje veoma dugo, zahteva milimetarsku preciznost i veliko strpljenje doktora koji izvodi proceduru.

Mapiranje i ablacija aritmogenih žarišta je tradicionalno rađeno endokardnim (uvođenjem ablacionoh katetera kroz krvne sudove) pristupom. Međutim, kod nekih bolesnika žarište tahikardije nalazilo se duboko u enodokardu, a kod pojedinih čak i subepikardno. Takvim žarištima nije moguće pristupiti i uraditi ablaciju endokardnim pristupom pa samim tim ni eliminisati aritmiju. Epikardni pristup se takođe, radi i kod bolesnika kod kojih predhodne endokardne ablacije nisu dale rezultat odnosno aritmija nije prestala.

\section{SESTRINSKE INTERVENCIJE U PRIPREMI BOLESNIKA ZA EPIKARDNU ABLACIJU}

Jedan od bitnih elemenata uspešnog lečenja je adekvatna priprema bolesnika za ablaciju. Ona sadrži sve elemente kao i priprema bolesnika za bilo koju drugu intervenciju. Sestre moraju biti dobro edukovane da bi mogle da daju odgovore na sva pitanja koja im bolesnici u okviru pripreme mogu postaviti. Dobro obučena sestra poznaje i sve faze toka epikardne ablacie i objašnjava ih bolesniku u cilju ostvarivanja što bolje saradnje. Dobro pripremljen bolesnik je u stanju da dobro sarađuje u svim fazama lečenja jer zna šta se od njega očekuje.

\section{Psihička priprema}

Psihička priprema počinje od momenta prijema bolesnika u bolnicu. Pripremu započinje lekar postavljanjem dijagnoze, objašnjavanjem prirode njegove bolesti i da je epikardna ablacija jedino rešenje njegovog problema. Lekar je u obavezi da objasni bolesniku tok procedure, rizike koje ona donosi kao i šta može da mu se dogodi ukoliko ne pristane na intervenciju. Sestra nastavlja pripremu na odeljenju objašnjavajući mu sve dijagnističke postupke kojima je podvrgnut, tok procedure i kako treba da se ponaša za vreme i nakon ablacije. Sestra trba još jednom da skrne pažnju bolesniku da će nakon ablacije imati plasirane šitove u prepone, ispod grudne kisti i ispod vrata i da će to od njega zahtevati mirovanje $\mathrm{u}$ postelji najverovatnije dva dana.

\section{Laboratorijska priprema}

Podrazumeva uzimanje krvi za različite vrste analiza koje su neophodne radi procene stanja bolesnika i funkcije organa pre i posle intervencije. U slučaju da analize pokažu postojanje nekog infektivnog žarišta ablacija se odlaže do saniranja. Sestra občno uzima krv za laboratorijeske analize iz kubitalne vene u odgovarajuće epruvete i odnosi u laboratoriju radi analiziranja. Prispele analize pokazuje doktoru i ulaže u istoriju bolesti.

Laboratorijsko ispitivanje krvi podrazumeva dve vrste analiza: one koje su usmerene na ispitivanje vrste, broja, odnosa, izgleda ćelijskih elemenata krvi (krvna slika, hematološki parametri) i druge kojima se proverava biohemijski sastav krvi i na osnovu toga ustanovljava rad ili stanje pojedinih organa ili tkiva:

- Krvna slika, se radi zbog procene opšteg zdravstvenog stanja i otkrivanja raznih poremećaja poput anemija, infekcija i dr. KKS uknjučuje broj eritrocita, leukocita, trombocita, hemoglobin i hematokrit.

- Sedimentacija, se koristi za otkrivanje i praćenje zapaljenskih porcesa.

- Biohemijskim analizama, utvrđujemo stanje pojedinih organa: ispitivanje stanja srca, jetre, bubrega, lipidni status, metabolizam glukoze, elektrolite odnosno određujemo parametre kao što su :natrijum, kalijum, kalcijum, magnezijum, glukoza, urea, kreatinin, ALT, AST,LDH, CK, CK-MB, holesterol, trogliceridi,proteini, albumini, gvožđe, feritin, CRP. - Protrombinsko vreme je još jedna od standardnih analiza i služi za određivanje brzine zgrušavanja krvi (pojedini lekovi dovode do produženja ovog vremena).

Krvna grupa i RH faktor zbog ozboljnih neželjenih reakcija koje prate davanje $\mathrm{ABO}$ inopatibilne teansfuzije, testiranje krvne grupe je važno kod svih bolesnika kojima terba da se uradi epikardna ablacija srca.

- APTT, PTV, INR, koristi se za određivanje skolnosti krvi ka zgrušavanju, može biti produžen kod nekih bolesti jetre, uzimanja lekova protiv zgrušavanja krvi. U slučaju da je ovo vreme produženo intervencija se odlaže.

- Analiza urina, je najčešće korišćen test za brzu procenu zdravstvenog stanja. Analizira se boja, miris, kiselost i specifična težina kao i prisustvo određenih materija koje se normalno u njoj ne nalaze a mogu da nam ukažu na bolest ili stanje koje predhodi nastanku bolesti.

- Radiografija srca i pluća, je nativni rentgenski pregled koji daje podatke o izgladu, položaju, veličini kao i o promenama u strukturi srca i pluća.

\section{Klinička priprema}

Podrazumeva prikupljanje rezultata svih dopunskih testova i dijagnostičkih procedura koji su bolesniku rađeni nakon prijema i njihovo ulaganje $\mathrm{u}$ istoriju bolesti. Sestra vodi računa o tome da sve analize koje je doktor tražio u okviiru pripremu budu uložene i istoriju bolesti i nasložene po unapred dogovorenom redosledu. Neophodno je da se $\mathrm{u}$ istoriji bolesti nalazi potpisana sglasnost bolesnika da je upoznat sa procedurom i rizicima lečenja i da prihvata predloženu meru lečenja bez obzira na potencijalne rizike.

\section{Fizička priprema}

Obuhvata skup postupaka koje bolesnik i sestra treba da urade za što bolje izvođenje intervencije a u cilju smanjenja komplikacija i prenosa infekcije kroz ubodno mesto.

\section{Dan pre intervencije:}

- Doktor obaveštava bolesnika da je stavnjen na program i da će mu planirana ablacija biti urađena sutra. Sestra tada obaveštava bolesnka da počonju i neposredne pripreme za ablacuju.

- Sestra bolesniku saopštava da sme da lagano večera i do ponoći da pije tečnosti, a posle ponoći je zabranjeno bilo šta da jede i pije.

- Potrebno je pitati bolesnika da li ima redovnu stolicu, ukoliko nije imao stolicu duže od tri dana neophodno je dati klizmu.

- Neophodno je obrijati ubodna mesta: donji deo stomaka, prepone i grudi.

- Posle brijanja je obavezno kupanje baktericidnim sapunom i oblačenje čiste pidžame.

- Plasirati intravensku kanilu kroz koju će dobijati lekove i tečnost.

- Treba ispitati bolesnika o eventualnoj alergiji na jod radi blagovremene pripreme.

- Treba dobiti pismenu saglasnost bolesnika za epikardnu ablaciju srca, da je upoznat sa procedurom i da prihvata eventualne rizike lečenja.

\section{Na dan intervencije:}

- Sestra bolesnniku radi EKG, meri pritisak i temperatiru i rezultate beleži u medicinsku dokumentaciju.

- Nalaže bolesniku da se još jednom okupa baktericidnim sapunomi obuče čistu pidžamu.

- Po nalogu doktora bolesniku uključuje infuziju i daje lekova (za smiranje i antibiotik).

- Proverava da li je bolesnik izvadio zubnu protezu ukoliko je ima. - U predviđeno vreme sestra odvozi bolesnika sakrevetom i kom- 
pletiranom istorijom bolesti u angio salu gde ga preuzimaju sestre instrumentarke.

\section{TEHNIKA IZVOĐENjA EPIKARDNE ABLACIJE}

Bolesnik, predhodno dobro pripremljen od strane doktora i sestara na odeljenju, leže na pokretni sto u angio sali . Prvo ga treba povezati na monitor i proveriti prohodnost venskog puta. Braunila, zbog položaja na stolu i lakšeg pristupa sestara koje rade u sali, mora biti plasirana u desnu ruku. Zbog dužine intervencije sestre bolesniku plasiraju urinarni kateter . Na taj način je obezbeđeno mirovanje bolesnika kao i olakšana kontrola bilansa tečnosti za vreme procedure. Bolesniku se tada uključuje koseonik preko maske za nos i usta. Posle sterilnog pokrivanja bolesnika sestra pomaže doktoru da obuče sterilan mntil i rukavice. Sestra tada otvara sterilan set koji je pripremija i koji sadrži sve što je neophodno za plasiranje šitova kao i za kompletnu proceduru.

U sali za ablaciju uvek je neophodno da se nalaze dva doktora elektrofiziologa, dve sestre instrumentarke i rentgen tehničar. Ispred sale za kompijuterskom opremom nalazi se inžinjer koji pomaže doktoru u tumačenju podataka dobijenih sa katetera radi lakšeg i bržeg mapiranja.

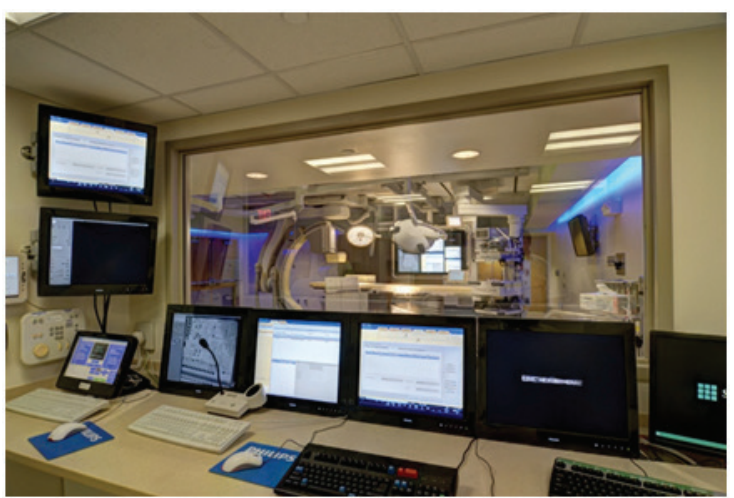

sl 1. Monitoring ispred sale za epikardnu ablaciju

Koža u subksifoidnom regionu se dezinfikuje i anestiše jednoprocentnim lidokainom. Procedura se izvodi u opštoj anesteziji. Za punkciju se koristi standardna igla promera 17 a dužine 3,5 ili 6 inča. Igla se okreće prema levom ramenu i punkcija se vrši između leve strane ksifoidnog nastavka grudne kosti i levog grudnog koša. Kako se igla kreće dalje prolazi kroz oblastizmeđu dijafragme i zida grudnog koša i pošto je fibrozni perikard ispupčen može se osetiti njegovo pulsiranje . Ubrizgavanje male količine kontrasta pokazaće lokaciju vrha igle. Sve ovo treba izvoditi veoma oprezno zato što i najmanji pokret iglom može doesti do probadanja srčanog mišića. Kada prestane otpor igla se tada nalazi u perikardu i tada se uvodi gajd (žica vodilja). Preko gajda se uvodi šit koji tu ostaje do karja procedure i 72 sata nakon ablacije se vadi. Kroz šit se zatim ubacuje kateter za ablaciju.Precizno mapiranje i sama ablacija moraju da se rade veoma obazrivo zbog prisustva korinarnih krnih sudova kiji u slučaju neprecizne manipulacije mogu biti oštećeni. Mala količina krvi je uvek prisutna, a u perikardu se normalno nalazi i od $50 \mathrm{ml}$ tečnosti. Aspiracija tečnisti se vrši na 15-20 minuta da ne bi dišlo do tamponade. Po završetku procedure ablacioni kateter se vadi i ubacuje pigteil kateter koji služi za aspiraciju tečnosti iz perikardnog prostora i kao kontrola da nema perikardnog krvarenja.

Zbog preciznijeg mapiranja vrši se i punkcija vena u preponama, postavljaju šitovi pomoću kojih se veliki brij katetera dovodi do određenih mesta u srcu: desna predkomora, leva predkomora, koronarni sinus. Oni šalju svoje signale u računar i olakšavaju precizniju orjentaciju i mapiranje aritmogenog žarišta.
Prilokom intervencije se ubrizgava i kontrastno sredstvi koje ocrtava tačan pložaj katetera u srcu i perikardu. Po potrebi u toku interencije doktor ordinira određene lekove, među kojima i Heparin koji sprečava nastanak trombova na kateteru, naravno ordinaranu terapiju sprovodi sestra.

Po završenoj ablaciji doktor izvlači katetere dok šitovi ostaju, zbog toga što je bolesnik dobio Heparin koji utiče na mogućnost uspostavljanja hemostaze.

Pigtail kateter može ostati u perikardu koliko god je smatramo neophodanim. Ultrazvučna kontrola se vrši veoma često da bi na vreme primetili postojanje eventualnog krvaranja i preduzeli adekvatne mere. U cilju prevencije infekcije koja može dovesti do nastanka perikarditisa i endokarditisa neophodno je primeniti intravensku antibiotsku terapiju.

Po završenoj ablaciji pacijenta sa stola prebacuju u krevet i on se transportuje na odeljenje gde će sestre nastaviti praćenje bolesnikovog stanja.

Sesre koje su učestvovale u ablaciji tada raspremaju ubotrebljeni materijal, peru i dezinfikuju salu, prave i sterilišu setove sa potrebnim materijalom za ablaciju. Po završenom čišćenju sala se steriliše upotrebom ultravioletnog zračenja i sprema za sledću proceduru.

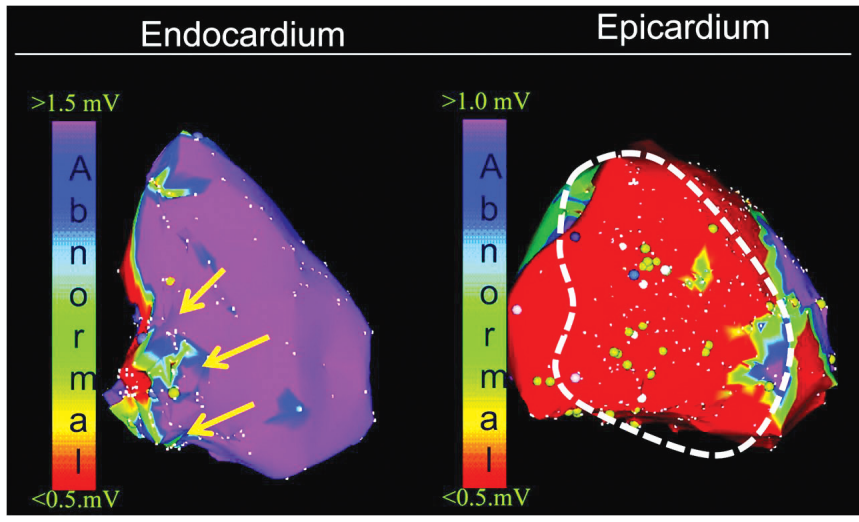

sl 2. Mapiranje izvora tahikardije

\section{Komplikacije}

Kao što se može i očekivati ulazak i ablacija u perikardnom prostoru se povezuju sa nekoliko mogućih komplikacija:

- Kada se pristupa perikardnom prostoru jetra, debelo crevo i dijafragma sa svojim vaskularnim dovodima mogu biti povređeni.

Ako se igla ubaci predaleko ili previše brzo može ući u levu srčanu komoru, u pleuralni prostor ili plućno krilo. Ako se za punkciju koristi igla sa zakrivljenim vrhom smanjuje se mogućnost povrede leve komore.

Izbegavanje oštećenja koronarnih arterija je veoma bitno. Koronarni angiogarm pokazaće lokaciju koronarnih arterija u odnosu na predloženo mesto ablacije koja se ne vrši ako je rastojanje između vrha katetera i najbliže arterije manje od $1 \mathrm{~cm}$.

Novi metodi koji bi omogućili da perikardni pristup bude manje rizična i jednostavnija procedura se razvijaju. Zaštita koronarnih arterija i okolnih struktura ostaće bitna odlika rada u ovom prostoru.

\section{SESTRINSKE INTERVENCIJE I PROCENA STANJA PO ZAVRŠENOJ EPIKARDNOJ ABLACIJI}

Epikardana ablacija srca je invazivna metoda lečenja koja sa sobom nosi velike rizike kako u toku procedure tako nekoliko sati posle. Sve komplikacije koje se jave neposredno po završenoj proceduri su potencijalno životno opasne. Zbog toga je neophodno da 
sestra bude stalno pored bolesnoka prva četiri sata. Sestra koja se nalazi pored bolesnika kojem je uržena epikardna ablacija mora da zna koje se komplikacije mogu javiti, da prepozna rane simptome i da odmah tozove ostale članove tima radi preduzimanja adekvatnog lečenja. Posle četiri sata sestra će vršiti pojačani nadzor a posle šest sati češće obilaziti bolesnika bez potrebe za stalnim prisustvom .

Posle završene epikardne ablacije bolesnika iz angio sale dovoze na odeljenje u bolesničkom krevetu u pratnji sestre instrumentarke, koja je učestvovala u ablaciji, koja odeljenskoj sestri skreće pažnju na sve nepravolnosti koje su sa desila za vreme intervencije. Zbog dužine trajanja intervencije (neki put može trajati i do sedam sati), osiguravanje apsolutnog mirovanja (de bi se sprečile moguće komplikacije), bola i kompleksnosti same intervencije bolesnik je uspavan, ima plasiran urinarni kateter da bi sestra u sali vodila računa o diurezi kao i da ne bi došlo do nekontrolisanog ispuštanja mokraće za vreme intervencije. Perikardni pigtejl je spojen sa drenom. U većini slučajeva zbog udruženog pristupa iz više mesta ima šitove u preponama. Soba u koju se smešta bolesnik po završenoj epikardnoj ablaciji treba da bude prostrana, da bude opremljena invazivnim monitorom i da ima dovod kiseonika.

1. Sestra bolesniku po smeštanju u sobu stavlja elektrode i povezuje ih sa monitorom da bi kontinuirano pratila srčani ritam, frekvencu i izgled EKG krivulje, stavlja manžetnu za merenje pritiska i preko pulsnog oksimetra prati razmenu gasova. Proveravanje vitalnih znakova vrši se na 15 minuta u prvih sat vremena, nakon toga na 30 minuta u toku prva 4 sata i posle toga na 2 sata do vađenja perikardnog pigtejla. Sve dobijene parametre beleži u medicinsku dokumentaciju i o svim promenama na vreme obaveštava lekara.

2. Kontrola prohodnosti disajnih puteva i oksigrnacija su veoma bitni za praćenje stanja bolsnika. Svi savremeni monitori imaju i dodatak za pulsnu oksimetriju. Taj nastavak se stavlja na bolesnikov prst i na taj način kontinuirano na monitoru prati saturacija. U slučaju pada saturacije sestra odmah bolesniku stavlja kiseoničku masku i uključuje kiseonik brzinom od 4 litra na sat. Pad saturacije koji može biti posledica dejstva anetetika je najčešći, ali udružen sa drugim simptomoma kao što su kašalj i iskašljavanje sukrvičavog ispljuvka, bol prilikom udisanja i dr može da bodu znak veoma ozboljnih komplikacija kao što su pneumotoraks i plućna embolija Sestra odmah obaveštava doktora. Dalje korake preduzima po nalogu doktora.

3. Pošto je prilikom ablacije dobio anesteziju bolesnik je neposredno po dilasku na odeljenje uspavan. Sestra prati buđenje bolesnika. Kada primeti da je bolesnik počeo da se budi ona mu saopštava da je ablacija završena, da se nalazi u sobi i da sada treba da miruje kako mu je to već objasnila $u$ okiru pripreme.

4. Neophodna je kontrola ubodnih mesta kako bi se na vreme primetilo krvarenje porad njih. U koliko krvarenje postoji sestra stavlja kesu sa peskom umotanu u sterilnu kompresu i obaveštava doktora, dalje korake preduzima po nalogu lekara.

5. Iz šita koji se nalazi ispod grudne kosti koroz koji je rađena epikardna ablacija izlazi pigteil na koji je nastavljen vakum dren. Vakum dren se kači sa strane kreveta.i služi za drenažu sadržaja iz perikarda. Pojava seroznog sadržaja sa blagim primesama sukrvice je normalanai nije neophodno obaveštavati doktora . Pojava male količine krvi u drenu takođe nije zabrinjavajuće ali zahteva pojačan nadzor i sestra mora da obavesti lekara. Velika količina izdrenirane krvi (oko $100 \mathrm{ml}$ ) odjednom je urgentno stanje jer može da bude posledica komplikacije same intervenicje, što bi značilo da je prilikom punkcije proboden zid srčane komore ili oštećena neka od koronarnih arterija u čijoj blizini je rađena ablacija. Ovo je veoma hitno stanje jer može dovesti di iskrvarenja zato što je bolesnik u sali prilikom ablacije dobio heparin koji onemogućava priordme mehanizme za zaustavljanje kevarenja. Bolesnik je životno ugrožen i zahteva hitnu kardiohirušku operaciju. Odmah obaveštava doktora i vadi krv za kontrolu krvne slike i trebovanje krvi. Dalje korake poreduzma po nalogu lekara i priprema bolesnika za eventualno hirško lečenje.

6. Kontroliše prolaznost venskog puta jer se svi lekovi u hitnim slučajevima daju venski. Prohodan venski put može da spasi život bolesniku u slučaju nastanka neke od komplikacija. Antibiotici koji služe kao prevencija infekcije daju se isključivo intravenski kao i rastvori koji služe za korigovanje elektrolitnog statusa, sprečavanje dehidracije i održavanje diureze. Veoma je važno pratiti izgled okolnog tkiva jer pojava crvenila na mestu gde je plasirana braunila goviri o nastanku tromboflebotisa. U tom slučaju neophodno je plasiranje nove braunile a predhodnu izvaditi i staviti topli oblog.

7. Kesu urinarnog katetera kači za bolesnički krevet i nastavlja posmatranje izgleda mokraće, vodi računa o eventualnoj pojavi hematurije, i vodi računa o diurazi i sva zapažanja notira u predviđenu medicinsku dokumentaciju i blagovrameno obaveštava lekara.

8. Uzima krv za analize - odmah po smeštanju u bolesnički krevet uzima krv za kontrolu krvne slike i elektrolitnog statusa i obaveštava lekara u slučaju odstupanja nekog parametra.

9. Bilans tečnosti je patametar koji nam pokazuje odnos između unete tečnosti i diureze. On je jako bitan parametar kod svih srčanih bolesnika. Pokazuje stanje kardiovaskularnog sistema i bubrežnu funkciju. Ponekad bolesnici mogu da imaju akutnu bubrežnu insuficijenciju koju može da isprovocira davanje kontrasta. Neophodno je da sestra na vreme primeti da je unos tečnosti veći od izmokrenog i da obavesti doktora radi preduzimanja adekvatnog lečenja.

10.Obaštava ultrazvučni kabinet da je bolesniku završena ablacija i da za dva sata dođu da urade ultrazvučnu kontrolu perikardnog prostora u cilju ranog otkrivanja pojave perikardnog izliva koji može da obude mali i zahteva samo praćenje ili veliki sa pretećom tamponadom srca i zahteva hitnu kardiohirušku operaciju. Ultra zvuk je metoda kontrole koja je najčešće koristi jer je neinvazivna, ne zrači i daje najbolji uvid u stenje srca i srčane kese. Radi se posle dva sata od ablacije, zatinm posle šest sati od završene ablacije a potom jednom dnevno do otpusta.

11. Posle četiri sata od završetka ablacije sestra podseća doktora da je vreme da se šitovi izvade. Hemostaza se vrši metodom digitalne kompresije. Dužnost sestre je da po uspostavljenoj hemostazi zalepi kompresivni valjak na ubodno mesti i često kontroliše postignutu hemostazu (da nema krvarenja ili hematoma).

12. Daje medinkamentoznu terapiju po nalogu lekara.

13. Vodi računa o ličnoj higijeni bolesnika, higijeni bolesnikovog rublja i postelje. Uslučaju da se dekonektira urinarni kateter od urinarne kese ili da se iz bolo kog drugog razloga posteljina isprlja mora biti promenjena. To rade dve sestre. Pre i posle svakog obroka bolesniku se donese pribor za pranje ruku kao i za pranje zuba.

14. U koliko nije dišlo do pojave komplikacija bolesniku se šest sati od završene intervencije dozvoljava unos hrane i vode.

15. Bolesnik može da sedi u krevetu sutradan po završenoj epikardnoj ablaciji, a da prošeta tek nakon vađenja perikardnog 
pigtejla.

16. Perikadrni pigtejl vadi doktor najčešće 48 sati po završenoj epikardnoj ablaciji .

17. Meriti trmperaturu dvaput dneno da bi se na vreme uočila pojava infekcije.

18. Stalna komunikacija i zdravstveno-vaspitni rad sestre obavljaju stalno u svatom kontaktu sa bolesnikom. One posmatraju i neverbalne znakove koje šlje bolesnik jer se dešava da bolesnik ima neke tegobe koje neće da prijavi jer ne želi da smeta.Sestra sada predlaže bplesniku način ishrane i novi stil života u koliko bolesnik to želi.

19. Komunikacija i rad sa porodicom je još jean od zadataka sestre. Ona svojim stavom mora da uveri porodicu da je bolesnik u stručnim rukama da su svi članovi tima posvećeni lečenju i uspešnom oporavku bolesnika. Da će u slučaju pojave neke od komplikacija bolesnik biti hitni zbrinut kao i da će svaki od članova tima uptreebiti sve svoje znanje, veštine i iskustvo da do komplikacija ne dođe. Sestra u skladu sa svojim zvanjem edukuje porodicu o daljem ponašanju kada bolesnik ode kući.
20. Bolesnk se otpušta kući pokretan i u dobrom opštem stanju obično treći dan od završene ablacije srca.

Bez obzira na sve moguće komlikacije one se veoma retko dešavaju a sestra samo vrši rutinsko praćenje. Svaka sestra je edukovana da zna i prepozna sve simptime svih komplikacija koje se mogu javiti posle ovog poristupa ablaciji. Svako odstupanje mora da prijavi lekaru i preduzima daljekorake po nalogu lekara.

svojih ovlašćenja.

Kontinuirano stručno usavršavanje sestara ima za cilj sticanje novih znanja i veština kroz stalno praćenje stručne sestrinske literature i novih tehnologija i načina lečenja, razmenu iskustava, kao i stručno usavršavanje sa proverom teorijskog i praktičnog znanja.

Vođenje sestrinske dokumentacije i stručno planiranje zdravstvene nege su kamen temeljac za razvoj sestrineke profesije u budućnosti. To će sestrama dati naučnu i dokumentovanu osnovu za stručne radove. Istraživanja u oblast sesrinsta imaju za cilj unapređenje zdravstvene nege i njenu prilagodljivost potrebama svakog bolesnika.

\section{Zaključak}

Setrinstvo je kompleksna profesija čije usluge variraju od običnih rutinskih i manuelnih radnji do aktivnosti za koje je potreban visok stepen stručnog znanja i veština, sposobnost kritičkog mišljenja i rasuđivanja u primeni naučenih principa i izbora najboljih mera u datom trenutku.

Sestra je, pored lekara, osnovni član tima. Ona je stručnjak koji u skladu sa svojim kompeticijama, pruža najkvalitetniju, visokostručnu zdravstvenu negu i u svom domenu donosi odluke bazirane na naučnim, stručnim i etičkim principima i odgovorna je za rezultate svog rada.

Medicinska sestra mora biti emocionalno zrela i stabolna osoba kako bi mogla da razume i podnese ljudske patnje, hitna stanja, zdravstvene probleme i etičke nedoumice.

Mora biti brižna i sposobna za samostalni rad ali i za rad u timu i saradnju sa drugim profesijama u zdravstvu.

Ssetre u timu rade samostalno na unapređenju zdravlja, lečenju i rehabilitaciji. Pružaju zdravstenu negu, organizuju profesionalnu negu i kontinuiranu edukaciju. Sestrinska profesija je suočena sa brzim napretkom nauke i da bi mogla da što bolje i efikasnije radi svoj posao ona mora kontinuirano da se edukuje. Ulažući u sebe, svoje znanje i obrazovnje ona postaje član tima koji polako zauzima sve bitnije mesto. Dobro edukovane i obrazovane sestre više ne pružaju samo osnovnu negu bolesniku već rade samostalno u okviru

\section{Literatura}

1. Grupa autora : Sestrinske intervencije ; izdavač: Datastatus 2010 god, četvrto izdanje; prevedeno sa engleskog - naslov u originalu Nursing procedures; 2004 by Lippincot Williams \& Wilkins

2. Tijanić, M.,Đuranović, D., Rudić, R., Milović, Lj.: Zdravstvena nega i savremeno sestrinstvo, Naučna,Beograd, 2004.

3. Rudić, R.,Kocev, N., Munćan, B.: Proces zdravstvene nege, Beograd, 2005.

4. Rakić D.:Zdravstvenovaspitanje, Kum, Beograd 2001. B

5.http://www.heartrhythmcharity.org.uk/www/media/files/For_Patients/120703-FINAL-Catheter_Ablation_for_Cardiac_Arrhythmias_Booklet.pd 4.http://www.nhs.uk/ipgmedia/national/Atrial\%20Fibrillation\%20Association/Assets/NewCatheterAblation.pdf

6. http://www.ncbi.nlm.nih.gov/pmc/articles/PMC3513239/

7. http://content.onlinejacc.org/article.aspx?articleid $=1135582$

8. http://content.onlinejacc.org/article.aspx?articleid=1135582

9. $h$ ttp://sr.wikipedia.org/sr/Aritmija

10. http://sr.wikipedia.org/sr/\%D0\%A1\%D1\%80\%D1\%86\%D0\%B5

11. http://www.vita-maxima.org/saznajte-vise/atrijalna-fibrilacija/

12. http://www.stetoskop.info/Bolesti-srca-i-krvnih-sudova-Kardiologija-c29-p6-sicknesses.htm

13. http://nyp.org/health/wolff-parkinson-white.html

14. http://nyp.org/health/ventricular-tachycardia-fibrillation.html

15. http://www.bostonscientific.com/lifebeat-online/heart-smart/ventricular-arrhythmias.html

16. http://penn-medicine-clinical-reports.blogspot.com/2010/04/electrophysiology-research-update-2010.html

17. http://www.ncbi.nlm.nih.gov/pmc/articles/PMC1728572/pdf/v079p00059.pdf 